\title{
Hasil belajar dengan pembelajaran berbasis board game dalam mata pelajaran PPKn untuk mengembangkan skill berpikir kritis siswa
}

\author{
Nadya Putri Saylendra a, ${ }^{*}$, Lusiana Rahmatiani ${ }^{\mathrm{b}, 2}$, Agustinus Tampubolon ${ }^{\mathrm{c}, 3}$ \\ ab Pendidikan Pancasila dan Kewarganegaraan, Universitas Buana Perjuangan Karawang, \\ Indonesia \\ ${ }^{\text {C }}$ Pendidikan Kewarganegaraan, Universitas Pendidikan Indonesia, Indonesia \\ ${ }^{1}$ nadya.saylendra@ubpkarawang.ac.id* \\ *korespondensi penulis
}

\begin{abstract}
ABSTRAK
Penelitian ini bertujuan menjelaskan bagaimana hasil belajar dengan pembelajaran berbasis boardgame untuk mengembangkan berpikir kritis siswa dalam pembelajaran PPKn. Pendekatan yang digunakan dalam penelitian ini adalah pendekatan kualitatif dengan metode deskriptif. Adapun pengumpulan data menggunakan wawancara, observasi dan dokumentasi. Analisis data menggunakan triangulasi sumber. Hasil penelitian menunjukkan bahwa dalam hasil belajar dengan pembelajaraan berbasis boardgame untuk mengembangkan skill berpikir kritis siswa yaitu menunjukkan bahwa terjadinya perubahan sikap positif siswa, lebih kritis, mempunyai etos belajar yang baik, mampu mengeksplor pengetahuannya sendiri dan mampu bekerjasama dengan siswa yang lainnya.
\end{abstract}

\section{ABSTRACT}

This study aims to explain how learning outcomes using board game-based learning to develop students' critical thinking in PPKn learning. The approach used in this research is a qualitative approach with descriptive methods. The data collection uses interviews, observation and documentation. Data analysis using source triangulation. The results showed that the learning outcomes with boardgame-based learning to develop students 'critical thinking skills, which showed that there was a change in students' positive attitudes, were more critical, had a good learning ethos, were able to explore their own knowledge and were able to cooperate with other students.

\author{
Sejarah Artikel \\ Diterima : 15 Desember 2020 \\ Disetujui: 1 Maret 2021 \\ Kata kunci: \\ Hasil belajar \\ Inovasi Pembelajaran PPKn \\ Boardgame \\ Berpikir Kritis
}

Article's Information:

Received: 15 December 2020

Accepted: 1 March 2021

Keywords:

Learning outcomes

Civic Learning Innovation

Boardgame

Critical thinking

\section{Pendahuluan}

Rendahnya kemampuan berpikir kritis siswa menjadi tolok ukur proses pembelajaran di dalam kelas yang hanya menekankan pada model-model pembelajaran yang tidak mengakomodasi siswa mengembangkan kemampuannya. Misalnya proses pembelajaran di dalam kelas dilakukan hanya satu arah, hanya mencatat, menghapal dan sebagainya. Sehingga siswa hanya menggugurkan kewajibannya belajar dalam kelas tanpa mendapatkan keterampilan yang diperlukan bagi dirinya nanti ketika terjun ke masyarakat. Kemampuan berpikir kritis merupakan kegiatan penalaran yang dilakukan secara refleks atau tiba-tiba, kritis, kreatif, dan berorientasi pada proses pemikiran yang akan menghasilkan pembentukan suatu konsep, dan sebuah analisis (Iskandar, 2009). Proses tersebut dihasilkan dari pola pikir berdasarkan pengamatan, pengalaman, refleksi, tindakan, serta komunikasi. Dilihat dari pengertian tersebut, kemampuan berpikir sangat penting bagi siswa. Sementara itu, dalam mencapai tujuan pembelajaran diperlukan sinergi dan integrasi antara materi dan model pembelajaran yang akan diterapkan guru di kelas. Pemilihan model pembelajaran yang tepat tentu akan membantu guru sebagai fasilitator dalam mencapai tujuan pembelajaran. Dalam penelitian ini, model pembelajaran yang digunakan adalah model pembelajaran yang mengadopsi board game. Model ini diharapkan mampu menarik minat siswa dan mengakomodasi siswa untuk mengembangkan skill berpikir kritis. Maka dari itu, peneliti melakukan penelitian dengan judul 
Bagaiamana Hasil Belajar dengan Inovasi Pembelajaran Berbasis Board Game dalam Mata Pelajaran PPKn Untuk Mengembangakan Skill Berpikir Kritis Siswa.

\section{Metode}

Pendekatan dalam penelitian ini menggunakan pendekatan kualitatif dengan metode deskriptif. Lokasi penelitian adalah SMAK 1 Penabur Bandung. Subjek Penelitian adalah Guru PPKn dan Siswa Kelas XI. Adapun teknik pengumpulan data menggunakan wawancara, observasi dan studi dokumentasi. Sedangkan tahapan analisis data menggunakan reduksi data, display data dan penarikan kesimpulan.

\section{Hasil dan Pembahasan}

Guru PPKn menyatakan bahwa hasil yang dicapai dengan pembelajaran berbasis board game untuk mengembangkan skill berpikir siswa, sesuai dengan perencanaan pembelajaran, siswa dapat menjelaskan keputusan atas kasusnya jika terdapat perubahan. Siswa pun mempresentasikan hasilnya didepan kelas, selain itu semua siswa berhak memiliki kesempatan untuk berbicara. Ujian siswa pun berupa analisis mereka dapat menjelaskan contohnya mengenai hak. Siswa dapat menganalisis sesuatu yang berkaitan dengan materi kasus tersebut.

Wakil kepala sekolah mengatakan bahwa hasil pembelajaran PPKn menggunakan boardgame untuk mengembangkan skill berpikir kritis siswa sangat baik sekali, dilihat dari antusiasme siswa dalam mengikuti pembelajaran dan bagaimana jawaban-jawaban siswa atas pertanyaan-pertanyaan yang diberikan oleh guru maupun teman sekelasnya. Senada dengan pernyataan tersebut siswa menjawab bahwa hasil yang didapatkan siswa dalam pembelajaran PPKn berbasis board game adalah kemampuan berpikir kritis semakin berkembang, kreatif dalam mencari solusi, dan berkompetisi secara sehat dengan teman.

Untuk mengetahui bagaimana hasil belajar siswa dalam implementasi model pembelajaran Board Game untuk mengembangkan skill berpikir kritis siswa dalam mata pelajaran PPKn, dilakukan teknik analisa sebagai berikut.

Tabel 1 Triangulasi Sumber

Bagaimana hasil belajar siswa dalam implementasi model pembelajaran Board Game untuk mengembangkan skill berpikir kritis siswa dalam mata pelajaran PPKn

\begin{tabular}{|c|c|c|c|}
\hline \multirow{2}{*}{ Rumusan Masalah } & \multicolumn{3}{|c|}{ Triangulasi Sumber } \\
\hline & Waka Kurikulum & Guru PPKn & Siswa \\
\hline $\begin{array}{l}\text { Bagaimana hasil } \\
\text { belajar siswa dalam } \\
\text { implementasi model } \\
\text { pembelajaran Board } \\
\text { Game untuk } \\
\text { mengembangkan } \\
\text { skill berpikir kritis } \\
\text { siswa dalam mata } \\
\text { pelajaran PPKn }\end{array}$ & $\begin{array}{l}\text { Setelah dilaksanakannya } \\
\text { pembelajaran PPKn berbasis } \\
\text { boardgame pada materi } \\
\text { tentang peradilan di Indonesia, } \\
\text { terjadi perubahan pada } \\
\text { kemampuan siswa untuk berani } \\
\text { mengemukakan pendapat dan } \\
\text { solusi dalam pembelajaran di } \\
\text { kelas, siswa mampu berpikir } \\
\text { kritis dalam menghapi situasi- } \\
\text { situasi seperti menjawab } \\
\text { pertanyaan-pertanyaan yang } \\
\text { dilontarkan temannya. }\end{array}$ & $\begin{array}{l}\text { Pendekatan baru } \\
\text { dalam pembelajaran } \\
\text { dengan } \\
\text { menggunakan } \\
\text { boardgame, mampu } \\
\text { membentuk } \\
\text { kemandirian siswa, } \\
\text { meningkatkannya } \\
\text { kemampuan siswa } \\
\text { untuk mencari } \\
\text { pengetahuannya } \\
\text { sendiri, sikap siswa } \\
\text { menjadi lebih baik. }\end{array}$ & $\begin{array}{l}\text { Dampak dari } \\
\text { pembelajaran } \\
\text { berbasis } \\
\text { boardgame } \\
\text { dalam } \\
\text { pembelajaran } \\
\text { PPKn adalah para } \\
\text { siswa menjadi } \\
\text { aktif dalam } \\
\text { belajar, mandiri } \\
\text { dan terjadinya } \\
\text { perubahan sikap }\end{array}$ \\
\hline
\end{tabular}

Sumber: diolah oleh penulis, 2020 
Berdasarkan tabel di atas, dapat disimpulkan bahwa hasil yang didapatkan dalam pembelajaran berbasis boardgame dalam pembelajaran PPKn adalah tampak pada pengembangan kemampuan berpikir kritis siswa. Hal tersebut dapat diamati dari kegiatan siswa pada saat proses pembelajaran berlangsung. Untuk membahas hasil temuan penelitian di atas, peneliti merujuk kepada UU Sisdiknas No 20 Tahun 2003 Pasal (3), dikatakan bahwa:

"Pendidikan nasional berfungsi mengembangkan kemampuan dan membentuk watak dan peradaban bangsa yang bermartabat dalam rangka mencerdaskan kehidupan bangsa, bertujuan untuk berkembangnya potensi perserta didik agar menjadi manusia yang bertaqwa pada Tuhan Yang Maha Esa, berakhlak mulia, sehat, berilmu, cakap, kreatif, mandiri, dan menjadi warga negara yang demokratis dan bertanggung jawab".

Hilgard dalam Sanjaya (2007: 284) menyatakan bahwa "learning is the process by which an activity originates or changed through training procedures (wether in the laboratory or in the natural environments) as distinguished from changes by factors not attributable to training". Bagi Hilgard, belaar dipandang sebagai proses perubahan melalui kegiatan atau prosedur latihan baik di dalam laboratorium atau dalam lingkungan alamiah. Belajar bukanlah sekedar mengumpulkan pengetahuan. Belajar adalah proses mental yang terjadi dalam diri seseorang, sehingga menyebabkan munculnya perubahan perilaku. Aktifitas mental itu terjadi karena adanya interaksi individu dengan lingkungannya.

Ali (2007: 58-59) menyebutkan ada dua jenis dampak dari proses pembelajaran yaitu dampak pembelajaran (instructional effect) dan dampak pengiring (nurturant effect). Dampak pembelajaran yaitu dampak yang memang ingin dibentuk atau ingin dicapai sebagaimana telah dirumuskan dalam tujuan pembelajaran. Hasil pembelajaran ini dapat diukur, sebagai data hasil belajar siswa (angka atau nilai) dan berupa masukan bagi pengembangan pembelajaran selanjutnya. Sedangkan dampak pengiring yaitu dampak yang ikut terjadi akibat adanya proses pembelajaran. Hasil ini bukan tujuan yang ingin dicapai secara khusus sebagaimana tercantum dalam tujuan pembelajaran. Dampak ini bisa berupa terapan pengetahuan dan atau kemampuan di bidang lain sebagai suatu transfer belajar yang akan membantu perkembangan siswa mencapai kebutuhan dan kemandirian.

Dari uraian di atas maka dapat diterjemahkan bahwa belajar pada dasarnya adalah suatu proses aktifitas mental seseorang dalam berinteraksi dengan lingkungannya sehingga menghasilkan perubahan tingkah laku yang bersifat positif baik perubahan aspek pengetahuan, sikap dan keterampilan. Dikatakan positif oleh karena perilaku itu bersifat adanya penambahan perilaku sebelumnya yang cenderung menetap. Berdasarkan deskripsi dan pembahasan, dapat ditarik kesimpulan sebagai berikut: hasil pendekatan tersebut pembelajaran PPKn menunjukkan bahwa terjadinya perubahan sikap positif siswa, lebih kritis, mempunyai etos belajar yang baik, mampu mengeksplor pengetahuannya sendiri dan mampu bekerjasama dengan siswa yang lainnya. Walaupun hasil yang dimunculkan belum nampak secara signifikan, tetapi hasil ini sudah menunjukkan tren yang cukup positif.

\section{Simpulan}

Hasil belajar dengan pembelajaran PPKn berbasis boardgame secara signifikan dapat mengembangkan berpikir kritis kritis siswa. Hal tersebut dapat dilihat dari evaluasi yang dilakukan oleh guru PPKn dalam pembelajaran tersebut. Kemudian, terjadinya perubahan sikap positif baik dari aspek pengetahuan, aspek afektif maupun aspek psikomotor. Siswa menjadi lebih berpikir kritis, 
mempunyai etos kerja yang baik dan mampu mengeksplor pengetahuannya sendiri serta mampu bekerjasama dengan baik antar teman sebayanya.

\section{Ucapan Terima Kasih}

Terima kasih kepada Direktorat Penelitian dan Pengabdian Masyarakat Kementerian Riset dan Teknologi yang telah memberikan dana penelitian kepada peneliti.

\section{Referensi}

Harvey, B. S. (2002). Critical Thinking. A Companion to The Victorian Novel, 181-193.

Isman, A. (2011). Instructional Design in Education: New Model. Turkish Online Journal of Educational Technology - TOJET, 10(1), 136-142.

Istianah, Euis. 2013. "Meningkatkan Kemampuan Berpikir Kritis dan Kreatif Matematik dengan Pendekatan Model Eliciting Activities (MEAS) Pada Siswa SMA." Infinity Journal 2 (1): 43-54.

Sanjaya, W. (2008). Kurikulum dan Pembelajaran Teori dan Praktik Pengembangan Kurikulum Tingkat satuan Pendidikan (KTSP). Jakarta: Kencana.

Seel, Norbert M.; Lehmann, Thomas; Blumschein, Patrick; Podolskiy, Oleg A. (2017). Instructional Design for Learning | What is Instructional Design?. , 10.1007/978-94-6300-941-6(Chapter 1), 1-17. https://doi.org/10.1007/978-94-6300-941-6_1

Sukirman, D., \& Kasmad, M. (2006). Pembelajaran Mikro. Bandung: UPI Press

Undang-Undang No 20 Tahun 2003 Tentang Sistem Pendidikan Nasional 